\title{
A Conceptual Model for Strategic Decision Making in Malaysian Third-Party Logistics Industry
}

\author{
Chu-Le Chong ${ }^{1 *}$ \\ ${ }^{1}$ Faculty of Accountancy, Finance and Business, Tunku Abdul Rahman University College, Jalan Genting Kelang, Setapak, \\ 53300 Kuala Lumpur, Malaysia \\ *Corresponding author. Email: clchong@tarc.edu.my
}

\begin{abstract}
The world economic is going through unpredictability and local reactions are not precluded. The growing demands of third-party logistics (3PL) users and the appearance of increased 3PL have generated aggressive conflict in the 3PL industry to engage with the user firms. This is essential for 3PL to assess their competitive strategies to stay resourceful parallel to their rivals. This article focuses on the assessment of internal resources and capabilities prior to the evaluation of competitive strategic decision taken by 3PL in Malaysia to achieve financial performance in the track of the world's unpredictability. The firms' strategic approach is low costs and / or differentiation according to the perspective of Resource-Based View (RBV) theory. The findings show that the functional involvement influences the low cost and marginally lead to differentiation strategy. The outputs show that the capability of IT has a positive and slight effect on the application of differentiation than the low-cost strategy. This article concludes with directions for practitioners, government and future research in leveraging resources and capabilities to achieve financial performance.
\end{abstract}

Keywords: third-party logistics, RBV, functional involvement, capability of IT, competitive strategy, financial performance, Malaysia

\section{INTRODUCTION}

In the early of 1990 s, Malaysia was mainly reliant on Singapore logistics. Recently, Malaysian 3PL companies have arisen to offer the services in international standards. Not to mention the worldwide 3PL companies have also launched their centres in Malaysia. Thus, there is a promising expectation in the 3PL industry to take advantage of higher rate of return in Malaysia [1]. The expansion of the 3PL industry will pose a further threat and challenge to the logistics industry in Malaysia [2] [3].

To remain competitive in global market, firms are subcontracting their transport and logistics activities to 3PL companies. The aims of subcontracting are to reduce inventory level and increase flexibility to meet their clients' requirement. However, according to Custom Act Year 1967, firms are not allowed to sign up exceeding three 3PL companies to handle its customs brokerage in the shipment of goods. Therefore, 3PL users might be continued with a particular 3PL company and it would be difficult to pull such users apart from their current 3PL company.

The capability of 3PL companies rely on their competence to provide on-time and cheaper service [4]. In order to remain profitable, the cost and service pressures make 3PL to review other tactics to price their services offered to the clients [5]. Therefore, it is important for 3PL to make the right selections of low-cost and / or differentiation strategy to stay competitive in the 3PL industry [6-8].

These competitive pressures expect 3PL to review its internal resources and capabilities to accomplish better financial performance. Therefore, the purpose of this research was to solve two research questions which were 1) Does the internal resource or capability positively influence competitive strategy? 2) Does competitive strategy positively influence financial performance?

\section{LITERATURE REVIEW}

\subsection{Resource-Based View (RBV) Theory}

RBV has provided an essential conceptual framework to justify the competitive advantage of 3PL [9] based on their internal resource and capability [10]. Hence, RBV of the firm has become the notable approach used in strategic management literature to justify valuable resources or capabilities [11] [18], like unique assets and knowledge that could be used to attain competitive advantage in the market [12]. In the internal environment, tangible or intangible resources are defined as available stocks or assets that are owned by the firm [19] [20]. An example of tangible resource is the information technology (IT), which has become a strategic resource for 3PL owing to its unique competence leading to the evolution of logistics activities like the exploitation of Electronic Data Interchange (EDI) [13] [21] [22]. On the other hand, an example of intangible resource is the capability that is complex in a bundle of knowledge and experience exercised throughout the organisational procedures to achieve a better management of functional involvement [23]. Another example of intangible resource is the capabilities 
which refer to a company's skills in making decisions and managing its internal processes to achieve organisational objectives [24]. To make the right choice of competitive strategy, a firm intends to exercise its capabilities developed in the internal functional skills such as logistics, production, finance, marketing, etc. [26]. Hence, both functional involvement and capabilities of IT of a firm are considered as the capabilities that enable a 3PL firm to devise strategies and attain better firm performance.

\subsection{Functional Involvement}

Competitive strategies are developed and executed in the functional involvement of marketing, finance, human resource, and operations to archive the objectives of the organisation [28]. The operating field in a firm is segregated into different functions such as operations to provide a service to their clients, marketing to boost sales of the products and services, human resource to improve the effectiveness of organisations members, finance to administer financial resources [29], and information technology to collect and analyse data from suppliers [30]. Those functional involvements are often developed with the accumulation of technical knowledge, on-site training and working experience within the organisational process [23]. Making decision throughout different management functions enables exploitation of the wealth of knowledge and skills available in each operating field [31]. Therefore, this study applied the definition of functional involvement that provided by [8] which is the contribution of different management functions to form a strategy internally, that may lead to the choice of competitive strategy.

\subsection{The Capability of IT}

In this research, IT is referred to the hardware, software, operating system and other equipment that facilitate the management activities in the logistics industry [33-35]. Many researchers have provided evidence that the application of IT is the key instrument for 3PL firms to gain competitive advantage relative to their competitors [36]. Therefore, the capability of IT makes firms defend their market presence [11] [36]. For the purpose of this study, the capability of IT is referred as a competence to use IT by deploying hardware, software, operating system and other equipment to sustain business and operations [10]. IT hardware and software of themselves can neither bring benefits to company performance nor bring a competitive advantage to the firm [37]. Instead, RBV suggests such tangible resources to be bundled with people's skills to turn such inner or latent resources into capabilities for competitive advantage [38]. This study has IT qualified with people capabilities.

\subsection{The Competitive Strategy}

Porter's competitive strategy framework is extensively implemented to provide clearer understanding for strategic planning to operate business in its competitive environment
[39-42]. The rise of competitive strategic approach acknowledges the significance of competitive advantage resulting from the strategic decision made by the company [27] [37]. Hence, competitive advantage is part of a long-term strategy that could be performed better than its competitors and bring superior firm performance [44]. [45] described competitive strategy as a company's plan of action and implementation carried out by the organisation to compete with their competitors in the market. Following this line, the conceptualisation of competitive strategic by [39] that comprises of low cost and / or high differentiation compared to their rivals that has been widely adopted as a tool to increase the market share.

\subsection{Financial Performance}

Financial performance is referred as a measurement to evaluate the competency and productiveness of a firm [8]. It is significant as a part of the service provider evaluation factor [46-48]. To measure the financial performance of 3PL firms, there are various types of measurement items that have been adopted such as return-on-assets (ROA), market share [45], return-on-investments (ROI) and sales [16], sales volume, profitability [49], average growth in annual sales, average growth-rate in market share, revenue growth, percentage growth in ROA, percentage growth in ROI, percentage growth in return-on-sales (ROS), and overall financial performance [6] [13].

\subsection{Gaps of the Literature}

Most of the studies in 3PL are concentrated on developed regions like United States, Europe [50-52] and Australia [53]. This is consistent with [54] claiming that merely 15.6 percent of the 3PL research focused on Asian 3PL, while the remaining 3PL researchers assessed in United States. Since Asian countries have been identified as industrializing countries, current research has been extended to focus on Asian 3PL [55] in Singapore, China, Malaysia, etc. In Singapore, [56] adopted the Porter's competitive framework to evaluate the strategic positions based on its business performance in 3PL industry. Meanwhile, [57] examined the future use of 3PL. In China, [6], [7] and [8] evaluated the strategic and business performance of 3PL. [6] and [7] have extended the study of strategic position established by [56] to assess the connection between strategic choices and financial performance. Thereafter, [8] expanded 3PL research by focusing on environmental factors through operations strategies in 3PL and subsequently influence financial performance. In Malaysia, 3PL studies have been conducted by [58] [59] [60] and [61] with each having its scope. the studies did not evaluate the relationship among resource factors, competitive strategic decision making, and business performance. Hence, this research was meant to bridge the gaps of the literature by extending 3PL studies in Malaysian context with the conceptual model as displayed below. 


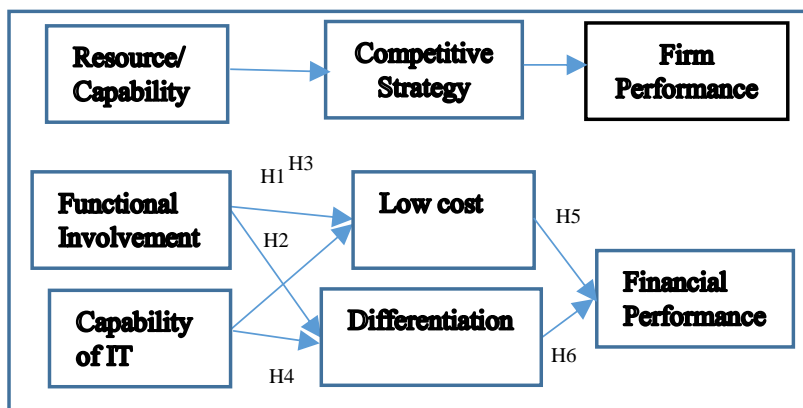

Figure 1 Conceptual Model for Strategic Decision Making

\subsubsection{Research Hypotheses}

To validate the model, the six relationships designated by the pointers in Figure 1 were analysed using the following six hypotheses as follows:

$\mathbf{H}_{1}$ : Functional involvement has a positive effect on low-cost strategy.

$\mathbf{H}_{2}$ : Functional involvement has a positive effect on differentiation strategy.

$\mathbf{H}_{3}$ : The capability of IT has a positive effect on low-cost strategy.

$\mathbf{H}_{4}$ : The capability of IT has a positive effect on differentiation strategy.

H5: Low-cost strategy has a positive effect on financial performance.

H6: Differentiation strategy has a positive effect on financial performance.

\section{RESEARCH METHODOLOGY}

This research used the quantitative method to obtain the data, as the survey questionnaire method was prevalently used in 3PL research. This data collection was conducted crosssectionally to solve the research questions using Statistical Package for Social Science (SPSS) software.

\subsection{The Variables of this Study}

This study adopted seven-point Likert scale to provide a more accurate result. The respondents were requested to assess the extent of the capability in using IT and the functional involvement in the making of business strategy to enhance the firm's financial performance. Please refer to Table 1 for variables and sources of measurement-items that were adopted in this research.

Table 1 Variables and Sources of Measurement-Items

\begin{tabular}{ll}
\hline Variables & Sources of Indicators \\
\hline $\begin{array}{l}\text { Functional } \\
\text { Involvement }\end{array}$ & Sum \& Teo [56]; Huo et al. [8] \\
Capability of IT & $\begin{array}{l}\text { Sum \& Teo [56]; Sum et al. [63]; Brah \& } \\
\text { Lim [21] }\end{array}$ \\
\hline Low Cost & $\begin{array}{l}\text { Huo et al. [8]; Zahra \& Covin [64]; Dess } \\
\text { \& Davis [65]; Schilke et al. [66] }\end{array}$ \\
\hline Differentiation & Huo et al. [8] \\
\hline
\end{tabular}

\begin{tabular}{ll} 
Financial & Sum \& Teo, [56]; Yeung et al. [6]; \\
Performance & Panayides [67]; Huo et al. [8] \\
\hline
\end{tabular}

\subsection{Sampling and Data Collection}

The companies that were registered with FMFF (Federation of Malaysian Freight Forwarders) and Malaysian Logistics Directory, have been considered as the survey base in this study. Based on [2], freight forwarders were similarly considered as third-party logistics (3PL) providers, that provide the value-added logistics services such as the loading and unloading of goods, transport intermodals, door-to-door pickup, delivery services, booking of storage space, and performing customs clearance for air and sea cargo.

\section{RESULTS}

There are 1307 companies found in the FMFF and Malaysian Logistics Directory. 163 sets of questionnaires were returned. Therefore, the effective response-rate was $12 \%$. The low response-rate was also experienced in other logistics researches. [6] and [8] have reported their response-rates as 12.6 percent.

\subsection{Demographic Characteristics}

Table 2 presented the demographics characteristics for the sample of 163 firms. Majority of the respondents (74.8\%) have been operating in Malaysia exceeding 11 years, whereas another $25 \%$ of the respondents were operating in the range of $2-10$ years. $83.4 \%$ of the respondents were local, $6.7 \%$ were international companies and $9.8 \%$ were joint ventures. In their key services offered in 3PL market, over than $31 \%$ of the respondents encountered fierce competition numbering exceeding 700 .

Table 2 Company Characteristics as the Respondents

\begin{tabular}{clcc}
\hline Profile & Description & $\begin{array}{c}\text { Frequency } \\
(\mathbf{n = 1 6 3 )}\end{array}$ & Percentage \\
\hline $\begin{array}{c}\text { Years of } \\
\text { operations in }\end{array}$ & 2 to 4 & 9 & 5.5 \\
Malaysia. & 8 to 10 & 14 & 8.6 \\
& 11 or more & 18 & 11.0 \\
& & 122 & 74.8
\end{tabular}

\begin{tabular}{|c|c|c|c|}
\hline \multirow{8}{*}{$\begin{array}{c}\text { Physical } \\
\text { assets }(\mathrm{RM})\end{array}$} & $<4,000,000$ & 96 & 58.9 \\
\hline & $4,000,000$ to & 16 & 9.8 \\
\hline & $8,000,000$ & & \\
\hline & $8,000,000$ & 9 & 5.5 \\
\hline & $12,000,000$ & & \\
\hline & $12,000,000$ to & 6 & 3.7 \\
\hline & $16,000,000$ & & \\
\hline & $>16,000,000$ & 36 & 22.1 \\
\hline \multirow{6}{*}{$\begin{array}{l}\text { Number of } \\
\text { major } \\
\text { competitors }\end{array}$} & 1 to 10 & 19 & 11.7 \\
\hline & 10 to 100 & 61 & 37.4 \\
\hline & 100 to 500 & 27 & 16.6 \\
\hline & 500 to 700 & 0 & 0 \\
\hline & 700 or more & 51 & 31.3 \\
\hline & Unknown & 5 & 3.0 \\
\hline
\end{tabular}


Table 2 Company Characteristics as the Respondents (Continued)

\begin{tabular}{|c|c|c|c|}
\hline Profile & Description & $\begin{array}{c}\text { Frequency } \\
(n=163)\end{array}$ & Percentage \\
\hline $\begin{array}{c}\text { Company } \\
\text { annual sales } \\
(\mathbf{R M})\end{array}$ & $\begin{array}{l}<1,000,000 \\
1,000,000 \\
3,000,000 \\
3,000,000 \\
6,000,000 \\
6,000,000 \\
9,000,000 \\
9,000,000 \\
12,000,000 \\
>12,000,000\end{array}$ & $\begin{array}{c}2 \\
52\end{array}$ & $\begin{array}{r}21.5 \\
19.6 \\
17.8 \\
8.0 \\
\\
1.2 \\
\\
31.9\end{array}$ \\
\hline
\end{tabular}

\begin{tabular}{cl|cc}
$\begin{array}{c}\text { Number of } \\
\text { full-time }\end{array}$ & Less than 50 & 115 & 70.6 \\
employees & $100-199$ & 19 & 11.7 \\
& $200-499$ & 10 & 6.1 \\
& $500-999$ & 18 & 11.0 \\
& 1000 or more & 1 & 0.6 \\
& & 0 & 0
\end{tabular}

\begin{tabular}{cl|cc} 
Number of & Less than 50 & 147 & 90.2 \\
part-time & $50-99$ & 5 & 3.1 \\
employees & $100-199$ & 10 & 6.1 \\
& $200-499$ & 0 & 0 \\
& $500-999$ & 1 & 0.6 \\
& 1000 or more & 0 & 0
\end{tabular}

\begin{tabular}{ll|cc} 
Ownership & Wholly local & 136 & 83.4 \\
& $\begin{array}{l}\text { Wholly foreign } \\
\text { Joint venture } \\
\text { (less than 30\% }\end{array}$ & 11 & 6.7 \\
local equity) & & 1.8 \\
Joint venture & 13 & 8.0 \\
(30\% or more & & \\
local equity) & &
\end{tabular}

\begin{tabular}{|c|c|c|c|}
\hline Position & $\begin{array}{l}\text { Top } \\
\text { Management } \\
\text { Senior/Executive } \\
\text { Vice President } \\
\text { Director } \\
\text { Manager } \\
\text { Others }\end{array}$ & $\begin{array}{c}4 \\
10 \\
65 \\
26\end{array}$ & $\begin{array}{c}2.5 \\
\\
6.1 \\
39.9 \\
16.0\end{array}$ \\
\hline
\end{tabular}

Source: Data Analysis Results (2020)

\subsection{Test of Non-Response Bias}

According to [73], late respondents are sharing the same attributes as non-respondents, because they show the unwillingness to be involved in the research. To detect the nonresponse bias, this study has made a comparison between 119 respondents (late-response) and 44 respondents that have responded in the first two weeks. Chi-square tests on demographic characteristics and independent-samples t-test between the two groups of responses on the five variables adopted in this research indicated no significant variances between the early and late respondents.

\subsection{Factor Analysis}

A factor analysis on the 36 indicators of the current study was performed using a principal axis factor extraction to determine the factor structure. The five factors with eigenvalues higher than one were removed, thus justifying a total of $71.98 \%$ of the variance on the full set of variables. A number of factor analyses were tested showing that the five factors are the most interpretable solution. An Oblimin rotation was conducted given that factors were predicted to be inter-related. In the first round of running the factor analysis, the items of IT2, Cost2, Diff6 and Diff12 were identified to have cross-loading values as $0.721,0.657,0.611$ and 0.608 due to greater than 0.50 , and therefore, were dropped in the subsequent round. In the second round of running factor analysis, all the conditions were satisfactorily fulfilled. In the Bartlett's test of sphericity, it assessed the entice magnitude of all the correlations within the correlation matrix, which was significant with the value $\left(\chi^{2}\right.$ (171) $7135.179, p<0.001$, showing that it was suitable to use the factor-analytic model on the data set. The Kaiser-MeyerOlkin assesses the fitness of this data set, and then it demonstrated strong relationships among variables $(\mathrm{KMO}=$ 0.796). This result indicated a good-to-go for further data analysis. The rotated-component matrix is presented in Table 3. Only the items with factor loadings above 0.40 are presented, supporting the inclusion of each item in the factor analysis.

\subsection{Reliability Test}

A reliability test has been conducted to every single factor to check whether the measurement items have internal stability and consistently measure the particular variable [74]. Reliability was assessed using the Cronbach's Alpha coefficients. The measures have an appropriate degree of reliability when Cronbach's Alpha figure are the same as or more than 0.70 [75]. Table 4 shows the Cronbach's Alphas ranging from 0.74 to 0.90 for the five variables. These figures go beyond the threshold of 0.70 .

Table 3 Variables and Item-Loadings

\begin{tabular}{|c|c|c|c|}
\hline Variables & Items & $\begin{array}{c}\text { Factor } \\
\text { Loadings }\end{array}$ & Communalities \\
\hline Functional & FI1 & 0.670 & 0.870 \\
\hline \multirow[t]{4}{*}{ Involvement } & FI2 & 0.779 & 0.856 \\
\hline & FI3 & 0.720 & 0.867 \\
\hline & FI4 & 0.853 & 0.614 \\
\hline & FI5 & 0.699 & 0.688 \\
\hline \multirow{11}{*}{$\begin{array}{l}\text { Capability of } \\
\text { IT }\end{array}$} & IT1 & 0.611 & 0.893 \\
\hline & IT3 & 0.666 & 0.875 \\
\hline & IT4 & 0.854 & $\mathbf{0 . 8 3 7}$ \\
\hline & IT5 & 0.880 & 0.831 \\
\hline & IT6 & 0.880 & 0.676 \\
\hline & IT7 & 0.927 & 0.827 \\
\hline & IT8 & 0.914 & 0.860 \\
\hline & IT9 & 0.914 & 0.623 \\
\hline & IT10 & 0.740 & 0.835 \\
\hline & IT11 & 0.758 & 0.955 \\
\hline & IT12 & 0.848 & 0.925 \\
\hline \multirow[t]{3}{*}{ Low Cost } & Cost1 & 0.745 & 0.627 \\
\hline & Cost3 & 0.817 & 0.859 \\
\hline & Cost 4 & 0.773 & 0.900 \\
\hline
\end{tabular}




\begin{tabular}{lccc}
\hline Differentiation & Diff5 & $\mathbf{0 . 9 2 1}$ & $\mathbf{0 . 8 4 0}$ \\
& Diff7 & $\mathbf{0 . 7 4 8}$ & $\mathbf{0 . 6 7 2}$ \\
& Diff8 & $\mathbf{0 . 7 9 6}$ & $\mathbf{0 . 8 3 9}$ \\
& Diff9 & $\mathbf{0 . 6 2 8}$ & $\mathbf{0 . 8 8 2}$ \\
& Diff10 & $\mathbf{0 . 9 2 0}$ & $\mathbf{0 . 8 4 3}$ \\
& Diff11 & $\mathbf{0 . 8 4 0}$ & $\mathbf{0 . 8 3 8}$ \\
& Diff13 & $\mathbf{0 . 8 7 7}$ & $\mathbf{0 . 8 6 0}$ \\
Financial & FP1 & $\mathbf{0 . 7 6 6}$ & $\mathbf{0 . 8 4 3}$ \\
Performance & FP2 & $\mathbf{0 . 7 9 6}$ & $\mathbf{0 . 8 3 8}$ \\
& FP3 & $\mathbf{0 . 6 7 8}$ & $\mathbf{0 . 8 6 0}$ \\
& FP4 & $\mathbf{0 . 7 2 9}$ & $\mathbf{0 . 8 2 0}$ \\
& FP5 & $\mathbf{0 . 8 5 6}$ & $\mathbf{0 . 8 7 8}$ \\
& FP6 & $\mathbf{0 . 8 5 4}$ & $\mathbf{0 . 8 4 4}$ \\
\hline
\end{tabular}

Source: Data Analysis Results (2020)

Table 4 Reliability-Test Results

\begin{tabular}{lcc}
\hline \multicolumn{1}{c}{ Variables } & $\begin{array}{c}\text { Items } \\
\text { Retained }\end{array}$ & $\begin{array}{c}\text { Cronbach } \\
\text { Alpha }\end{array}$ \\
\hline Functional Involvement & 5 & 0.862 \\
Capability of IT & 11 & 0.958 \\
Low Cost & 3 & 0.822 \\
Differentiation & 7 & 0.936 \\
Financial Performance & 6 & 0.951 \\
\hline
\end{tabular}

Source: Data Analysis Results (2020)

\subsection{Hypotheses Testing}

Multiple Regression Analysis (MRA) is an inferential statistic that is applied to investigate the co-relations between a set of independent variables and one dependent variable [76]. This section discusses the outcomes of hypotheses analysis in Figure 2. The figure revealed that the functional involvement and capability of IT can simultaneously interpret $38 \%$ of the variance identified in low-cost strategy $\left(\mathrm{R}^{2}=0.380, \mathrm{p}<0.01\right)$ and $29.4 \%$ of the variance found in differentiation strategy $\left(\mathrm{R}^{2}\right.$ $=0.294, \mathrm{p}<0.01$. Low cost and differentiation emphases contribute to the variable of financial performance by yielding an $R^{2}$ of $0.522\left(R^{2}=0.522, p<0.01\right)$. A thorough analysis on every variable shows that functional involvement $(\beta=0.617$, $\mathrm{p}<0.01)$ is a crucial determinant for low-cost strategy, except differentiation emphasis $(\beta=0.175, \mathrm{p}>0.01)$. This supports the hypothesis $\mathrm{H}_{1}$, while rejecting $\mathrm{H}_{2}$. Through the analysis, the capability of IT seems not to be a driver to determine the low-cost $(\beta=-0.272, p>0.01)$ and differentiation strategies $(\beta$ $=0.168, \mathrm{p}>0.01)$. A low-cost $(\beta=-0.063, \mathrm{p}>0.01)$ and differentiation strategy $(\beta=-0.156, p>0.01)$ were not consistently associated with the achievement of better financial performance.

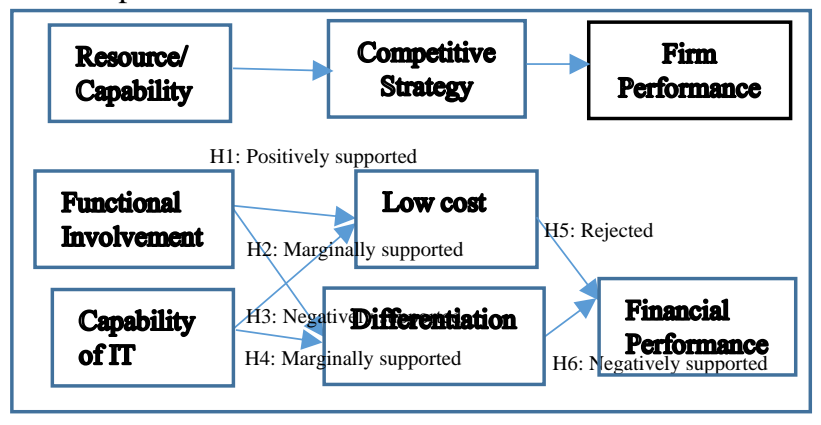

$* * \mathrm{p}<0.01(\mathrm{t}>2.33), * \mathrm{p}<0.05(\mathrm{t}>1.65)$

Figure 2 Conceptual Model with Hypothesis-Test Results

\subsection{Control Variables Analysis}

Table 5 presents the path coefficients and $\mathrm{R}^{2}$ changes values of the conceptual model. $\mathrm{R}^{2}$ is a coefficient-of-determination (CD) that measures the extent of robustness between the regression equation and the observed data [77]. Table 5 shows the percentage of $\mathrm{R}^{2}$ changes focused on financial performance around its mean value that can be influenced by the control variables. The table demonstrates that the direct effect of company age, physical assets, and annual sales on financial performance was not significant $(p>0.05)$, but the direct effect of number of employees and types of ownership were significant at 0.05 level. Though, the variance explained by the number of employees was 1.1 percent and the types of ownership was 2.8 percent on financial performance. Hence, all the control variables have been excluded in the analysis to predict financial performance.

\begin{tabular}{|c|c|c|c|}
\hline Variables & $\begin{array}{l}\mathbf{R}^{2} \\
\text { Changes }\end{array}$ & $\begin{array}{l}\text { Beta } \\
\text { Coefficient }\end{array}$ & t-value \\
\hline Company Age & 0.016 & 0.145 & 1.574 \\
\hline Physical Asset & 0.001 & 0.037 & 0.506 \\
\hline Annual Sales & 0.001 & 0.017 & 0.218 \\
\hline $\begin{array}{l}\text { Number of } \\
\text { Employees }\end{array}$ & 0.011 & $0.110^{*}$ & 2.203 \\
\hline $\begin{array}{ll}\text { Types of } \\
\text { ownership }\end{array}$ & 0.028 & $-0.237^{*}$ & 1.841 \\
\hline
\end{tabular}

$* * \mathrm{p}<0.01(\mathrm{t}>2.33), * \mathrm{p}<0.05(\mathrm{t}>1.65)$

Source: Data Analysis Results (2020)

\section{DISCUSSIONS}

Data analysis shows that the functional involvement is strongly influencing the low-cost strategy, while slightly influences the differentiation strategy. These findings contradict with [56] [8]. Their research found that functional involvement has a positive effect on the implementation of differentiation strategy; and functional involvement is not influencing the low-cost strategy. The result of this study could be inferred that Malaysian 3PL are not using the customeroriented strategy to meet customer requirement. This is supported by [32], which said that Malaysian 3PL are lacking of differentiation capability as they typically do not have essential guidance on how to provide solutions to their customers. Malaysian 3PL have less costly assets such as labours, building, storage facility, etc. that could drive them to pursue low-cost emphasis. Hence, the results of this research were in contrast with the previous works, because different countries are adopting different strategies.

$\mathrm{H}_{3}$ was negatively supported and it infers that emphasising the capability of IT would not lead to low-cost strategy. The reason behind is because of the cost that needs to be used to coach employee on how to utilise the IT. This is supported by [25] and [32], who claimed that the funding in IT seems to increase the cost in the service offering. Most of the Malaysian 3PL firms are not competent to use IT in their operational activities because of costs limitation and absence of skilled-IT specialists. Nevertheless, the results show that the capability of 
IT is slightly leading to differentiation strategy. This result infers that the capability of IT may enhance the service level and increases the competitiveness of the company by adding credibility to the application of RBV theory.

$\mathrm{H}_{5}$ was rejected because a 3PL firm that emphasises a low-cost strategy would experience slower growth in financial performance. This is because the firm may need to improve asset or sales turnover by lowering down the operating margins to gain sales volume [39]. A low-cost strategy would have restricted themselves to only provide core services, while the customer may ask for value-added logistics services to match their business [6]. Hence, these core services emphasise lowcost strategy leading to lower profitability.

$\mathrm{H}_{6}$ was negatively supported by showing that a differentiation strategy will bring an unsatisfactory financial performance. However, [6] found that a 3PL firm, that is capable to differentiate their product or service, will enjoy a better financial performance relative to those emphasising solely on low-cost strategy. This study challenged the previous research by claiming that the emphasising differentiation may bring a poorer financial performance. The dissimilarity of the results, which could be attached to the truth, is that the stipulation of differentiated services always requires higher cost [7] Furthermore, this is costly for a differentiator to maintain a premium price, because competitors could copy the differentiator's product or service effortlessly [24]. Due to the risk of copying, all differentiators must be cautious by not charging higher price than what the market can hold. There could be a threat, in which if the differentiation is exceeding customer needs, then it will force a compromise between the wasted funding in providing the differentiated services and revenue to secure a business [26].

\section{CONCLUSIONS}

The results show that functional involvement would help 3PL firms to rather deploy the low-cost than differentiation strategy. The capability of IT remains questionable towards the execution of differentiation strategy and the negative effect on the implementation of low-cost strategy. Lacking of IT specialists and the capability to implement differentiation strategy could be the main cause of the failure. Hence, the Malaysian government may offer incentives for 3PL firms to boost greater the utilisation of IT in international customs and trading to increase efficiency and effectiveness.

Low-cost and differentiation strategy are not the main drivers for 3PL firms to achieve superior financial performance. Since the implementation of differentiation strategy is having a negative effect on the achievement of better financial performance, the Malaysian government may put forward the standardised procedures to satisfy the service offering that is proposed by the 3PL firms.

In summary, this research has rendered valuable conclusions for researchers and practitioners to make a right competitive strategy by assessing their internal resources or capabilities to accomplish a better financial performance.

\section{LIMITATIONS}

This is worthwhile to share some limitations that were bound to this research. The scope of this research is the first limitation, because the results were analysed according to the data set collected from the 3PL firms in Malaysia. Hence, the result could not be generalised to other circumstances different from Malaysia. Likewise, the findings might be generalised among 3PL industry and have inadequate generalisability to other industries. This could be attributed to the fact that different industry does have various targets and strategic decisions which can be unique in order to stay competitive in the market. Second, this study only assessed two capabilities, which are functional involvement and the capability of IT upon low-cost and differentiation strategy, to drive financial performance. The result shows the variance that could be accounted in the financial performance variables, which was only 52.2 percent. The unaccounted variances could be explained by other resources or capabilities that are crucial for the survival of 3PL firms.

\section{FUTURE RESEARCH}

Further study could be carried out to resolve the limitations described aforementioned. First is the limitation of generalisability by only focusing on 3PL in Malaysia. It would be noteworthy to re-assess the hypothesized relationships to involve 3PL of different countries in order to get a greater generalisation. Further research could evaluate the competitive strategic requirements and decisions making among 1PL, 2PL, 3PL, and 4PL in Malaysia to gain superior financial performance. Second, future research is urged to gain greater than $\mathbf{5 2 . 2}$ percent variance to help firms focus on competitive strategic that could gain superior financial performance. This could be accomplished by including more independent variables, such as relational resources, technical resources, and managerial resources that may influence the choices of competitive strategic decision making and the achievement of higher firm performance in the 3PL industry.

\section{REFERENCES}

[1] Razak, H. N. H. A. (2011). Annual Report and the Audited Financial Statements of the FMHB (Freight Management Holding Berhad) and its subsidiaries (the 'Group') for the financial year ended 30 June 2011.

Retrieved from

http://fmmalaysia.listedcompany.com/chairman_statement .html

[2] Sgouridis, S. P. (2003). Freight transportation in Malaysia: technological and organizational issues from an ITS perspective (Vol. 1-46): Massachusetts Institute of Technology.

[3] Vasiliauskas, A. V., \& Jakubauskas, G. (2007). Principle and benefits of third party logistics approach 
when managing logistics supply chain. Transport, XXII (2), 68-72.

[4] Sohail, M. S., \& Sohal, A. (2003). The use of thirdparty logistics services: A Malaysian perspective.

Technovation, 23(5), 401-408.

[5] Ross, A., Jayaraman, V., \& Robinson, P. (2007). Optimizing 3PL service delivery using a cost-to-serve and action research framework. International Journal of Production Research, 45(1), 83-101.

[6] Yeung, H. Y., Selen, W., Sum, C. C., \& Huo, B. (2006). Linking financial performance to strategic orientation and operational priorities: An empirical study of third-party logistics providers. International Journal of Physical Distribution \& Logistics Management, 36(3), 210-230.

[7] Wang, Q., Zantow, K., Lai, F., \& Wang, X. (2006). Strategic postures of third-party logistics providers in mainland China. International Journal of Physical Distribution \& Logistics Management, 36(10), 793-819.

[8] Huo, B., Selen, W., Yeung, H. Y., \& Zhao, X. (2008). Understanding drivers of performance in the 3PL industry in Hong Kong. International Journal of Operation \& Production Management, 28(8), 772-800.

[9] Wong.C.Y., \& Karia, N. (2010). Explaining the competitive advantage of logistics service providers: A resource-based view approach. International Journal of production economics, 128(1), 51-67.

[10] Liu, X., Grant, D. B., Mckinnon, A. C., \& Feng, Y. (2010). An empirical examination of the contribution of capabilities to the competitiveness of logistics service providers: A perspective from China. International Journal of Physical Distribution \& Logistics Management, 40(10), 847-866.

[11] Wernerfelt, B. (1984). A Resource-based View of the Firm. Strategic Management Journal, 5(2), 171-181.

[12] Barney, J. B. (1991). Firm resource and sustained competitive advantage. Journal of Management, 17(1), 99121.

[13] Olavarrieta, S., \& Ellinger, A. E. (1997). Resourcebased theory and strategic logistics research. International Journal of Physical Distribution \& Logistics, 27(9/10), 559-587.

[14] Eisenhardt, K. M., \& Martin, J. A. (2000). Dynamic capabilities: What are they? Strategic Management Journal, 21(2000), 1105-1121.
[15] Helfat, C. E., \& Raubitschek, R. S. (2000). Product sequencing: Co-evolution of knowledge, capabilities and products. Strategic Management Journal, 21(10-11), 961979.

[16] Bharadwaj, A. S. (2000). A resource-based perspective on information technology capability and firm performance: An empirical investigation. MIS Quarterly, 24(1), 169-196.

[17] Teng, B. S., \& Cummings, J. L. (2002). Trade-offs in managing resources and capabilities. Academy of Management Executive, 16(2), 81 - 91.

[18] Newbert, S. L. (2007). Empirical research on the resource-based view of the firm: An assessment and suggestions for future research. Strategic Management Journal, 28(2), 121-146.

[19] Amit, R., \& Schoemaker, P. J. H. (1993). Strategic assets and organizational rent. Strategic Management Journal, 14(1), 33 - 46.

[20] Warren, K. (2002). Competitive strategy dynamics: Chichester: John Willey.

[21] Brah, S. A., \& Lim, H. Y. (2006). The effects of techno and TQM on the performance of logistics companies. International Journal of Physical Distribution \& Logistics Management, 36(3), 192-209.

[22] Calza, F., \& Passaro, R. (1997). EDI network and logistics management at Unilver-Sagit. Supply Chain Management, 2(4), 158-170.

[23] Day, G. S. (1994). The Capabilities of Market-Driven Organizations. Journal of Marketing, 58(4), 37-53.

[24] Hill, C. W. L., \& Jones, G. R. (2001). Strategic management theory: An integrated approach (5th ed.). Boston, New York: Houghton Mifflin Company.

[25] Johnston, R. (1999). Service operations management: return to roots. International Journal of Operations \& Production Management, 19(2), 104-124.

[26] Hitt, M. A., Ireland, R. D., \& Hoskisson, R. E. (2009). Strategic management: Competitiveness and globalization (concepts) (8th ed.): South-Western Cengage Learning.

[27] Porter, M. E. (1980a). Competitive Strategy: Techniques for Analyzing Industries and Competitors: Free Press, New York, NY. 
[28] Pearce II, J. A., \& Robinson JR, R. B. (1982). Formulation and implementation of competitive strategy: Irwin, Inc, United Stated.

[29] David, F. R. (1993). Strategic Management (4th ed.): New York: Macmillan.

[30] Alshawi, S. (2001). Logistics in the Internet age: Towards a holistic information and processes picture. Logistics Information Management, 14(4), 235-241.

[31] Grover, V., \& Malhotra, M. K. (1999). A framework for examining the interface between operations and information systems: Implications for research in the new millennium. Decision Sciences, 30(4), 901-920.

[32] Ali, R. M., Jaafar, H. S., \& Mohamad, S. (2008). Logistics and Supply Chain in Malaysia: Issues and Challenges. Paper presented at the EASTS International Symposium on Sustainable Transportation incorporating Malaysian Universities Transport Research Forum Conference 2008 (MUTRFC08), Universiti Teknologi Malaysia.

[33] Lai, K. H., Ngai, E. W. T., \& Cheng, T. C. E. (2005). Information technology adoption in Hong Kong's logistics industry. Transportation Journal, 44(4), 1-9.

[34] Lewis, I., \& Talalayevsky, A. (2000). Third-party logistics: Leverage information technology. Journal of Business Logistics, 21(2), 173-185.

[35] Kohli, R., \& Grover, V. (2008). Business value of IT: An essay on expanding research directions to keep up with the times. Journal of the AIS, 9(1), 23-37.

[36] Susana, G. A., João, F., \& João, L. (2007). The role of logistics' information and communication technologies in promoting competitive advantages of the firm. MPRA (Munich Personal RePEc Archive) Retrieved from http://mpra.ub.uni-muenchen.de/1359/

[37] Porter, M. E., \& Millar, V. E. (1985). How information gives you competitive advantage: The information revolution is transforming the nature of competition. Harvard Business Review, 149-174.

[38] Ravichandran, T., \& Lertwongsatien, C. (2005). Effect of information systems resources and capabilities on firm performance: A resource-based perspective. Journal of Management Information Systems, 21(4), 237276.

[39] Hall, W. K. (1980). Survival strategies in a hostile environment. Harvard Business Review, 58, 75-85.

[40] Nayyar, P. R. (1993). On the measurement of competitive strategy: Evidence from a large multiproduct U.S. firm. Academy of Management Journal, 36(6), 16521669.
[41] Geoffrion, M., \& Powers, F. (1995). Twenty years of strategic distribution system design: An evolutionary perspective. Interfaces, 25, 105-127.

[42] Spanos, Y. E., Zaralis, G., \& Lioukas, S. (2004). Strategy and industry effects on profitability: Evidence from Greece. Strategic Management Journal, 25(2), 139165.

[43] Cheng, L. C., \& Grimm, C. M. (2006). The application of empirical strategic management research to supply chain management. Journal of Business Logistics, 27(1), 1-57.

[44] Spulber, D. (2003). The intermediation theory of the firm: integrating economic and management approaches to strategy. Managerial and Decision Economics, 24(4), 253266.

[45] Robins, J., \& Wiersema, M. F. (1995). A resourcebased approach to the multibusiness firm: Empirical analysis of portfolio interrelationships and corporate financial performance. Strategic Management Journal, 16(4), 277-299.

[46] Sink, H. L., Langley Jr, C. J., \& Gibson, B. J. (1996). Buyer observations of the US third party logistics market. International Journal of Physical Distribution \& Logistics Management, 26(3), 38-46.

[47] Menon, M. K., McGinnis, M. A., \& Ackerman, K. B. (1998). Selection criteria for providers of third party logistics services: An exploratory study. Journal of Business Logistics, 19(1), 121-134.

[48] Liu, C. L., \& Lyons, A. C. (2011). An analysis of third-party logistics performance and service provision. Transportation Research Part E, 47, 547-570.

[49] Li, L. X. (2000). An analysis of sources of competitiveness and performance of Chinese manufacturers. International Journal of Operations \& Production Management, 20(3), 299-315.

[50] Leahy, S. E., Murphy, P. R., \& Poist, R. E. (1995). Determinants of successful logistical relationships: A third party provider perspective. Transportation Journal, 35(2), $5-13$.

[51] Lieb, R. C. (1992). The use of third-party logistics services by large American manufacturers. Journal of Business Logistics, 13(2), 29-42.

[52] Lieb, R. C., Millen, R. A., \& Van Wassenhove, L. N. (1993). Third-party logistics: A comparison of experienced American and European manufacturers. International Journal of Physical Distribution \& Logistics Management, 23(6), 35-44. 
[53] Dapiran, P., Lieb, R., Millen, R., \& Sohal, A. (1996). Third party logistics services usage by large Australian firms. International Journal of Physical Distribution and Logistics Management, 26(10), 36-45.

[54] Maloni, M. J., \& Carter, C. R. (2006). Opportunities for research in third-party logistics. Transportation Journal, 45(2), 23-38.

[55] Marasco, A. (2007). Third-party logistics: A literature review. International Jounal of Production Economics, 113(2008), 127-147.

[56] Sum, C. C., \& Teo, C. B. (1999). Strategic posture of logistics service providers in Singapore. International Journal of Physical Distribution \& Logistics Management, 29(9), 588-605.

[57] Bhatnagar, R., Sohal, A. S., \& Millen, R. (1999). Third party logistics services: A Singapore perspective. International Journal of Physical Distribution \& Logistics Management Decision, 29(9), 569-587.

[58] Zailani, S., Fernando, Y., \& Zakaria, H. (2010). Determinants of RFID adoption among logistics service providers in Malaysia: A discriminant analysis. International Journal of Logistics Systems and Management, 7(3), 345-367.

[59] Zakaria, H., Zailani, S., \& Fernando, Y. (2010). Moderating role of logistics information technology on the logistics relationships and logistics service quality. Operations and supply chain management, 3(3), 134-147.

[60] Karia, N., Wong, C. Y., \& Asaari, M. H. A. H. (2012). Typology of Resources and Capabilities for Firms' Performance. Procedia-Social and Behavioral Sciences, $65,711-716$.

[61] Karia, N., \& Wong, C. Y. (2012). The impact of logistics resources on performance: A survey of Malaysian logistics service providers. Production Planning \& Control: The Management of Operations and supply chain management, pp. 1-18. doi:

$10.1080 / 09537287.2012 .659871$

[62] Vickery, S. K., Droge, C., \& Markland, R. R. (1993). Production competence and business strategy: Do they affect business performance. Decision Sciences, 24(2), 435-456.

[63] Sum, C. C., Teo, C. B., \& Ng, K. K. (2001). Strategic logistics management in Singapore. International Journal of Operations \& Production Management, 21(9), 12391260.

[64] Zahra, S. A., \& Covin, J. G. (1993). Business strategy, technology policy and firm performance. Strategic Management Journal, 14, 451-478.
[65] Dess, G. G., \& Davis, P. S. (1984). Porter's (1980) generic strategies as determinants of strategic group membership and organizational performance. Academy of Management Journal, 27(3), 467-488.

[66] Schilke, O., Reimann, M., \& Thomas, J. S. (2009). When does international marketing standardization matter to firm performance? Journal of International Marketing, 17(4), 24-46.

[67] Panayides, P. M. (2007). The impact of organizational learning on relationship orientation, logistics service effectiveness and performance. Industrial Marketing Management, 36(1), 68-80

[68] Shang, K. C. (2009). Integration and organisational learning capabilities in third-party logistics providers. Service Industries Journal 29(3), 331-343.

[69] Murphy, P. R., \& Daley, J. M. (1994). Logistics issues in international sourcing: an exploratory study. International Journal of Purchasing\&Materials Management, 30(3), 22-27.

[70] Lai, F., Li, D., Wang, Q., \& Zhao, X. (2008). The information technology capability of third-party logistics providers: A resource-based view and empirical evidence from China. Journal of Supply Chain Management, 44(3), $22-38$.

[71] Sauvage, T. (2003). The relationship between technology and logistics third party provider. International Journal of Physical Distribution and Logistics Management, 33(3), 236-253.

[72] Knemeyer, A. M., \& Murphy, P. R. (2004). Evaluating the Performance of Third - Party Logistics Arrangements: A Relationship Marketing Perspective. Journal of Supply Chain Management, 40(1), 35-51.

[73] Armstrong, J. S., \& Overton, T. S. (1977). Estimating Nonresponse Bias in Mail Surveys. Journal of Marketing Research, 14(3), 396-402.

[74] Sekaran, U. \& Bougie, R. (2016) Research Methods for Business: A Skill Building Approach, 7th edition. New Jersey: Wiley Publications.

[75] Nunnally, J. (1978) Psychometric Theory, 2nd edition. New York: McGraw-Hill.

[76] Hair, J. J. F., Black, W. C., Babin, B. J., \& Anderson, R. E. (2010). Multivariate data analysis. Upper Saddle River, N.J: Pearson Prentice Hall.

[77] Bagozzi, R. P. (1994). Principles of marketing research: Blackwell Cambridge, Oxford, Mass. 